\title{
Review on Mould Contamination and Hygrothermal Effect in Indoor Environment
}

\author{
Yuyan He1, Qinghai Luo ${ }^{*}$, Peihong Ge ${ }^{2,3}$, Guojie Chen 1,2, Hanqing Wang ${ }^{2,3}$ \\ ${ }^{1}$ School of Civil Engineering, University of South China, Hengyang, China \\ ${ }^{2}$ Engineering Lab of Hunan for the Technologies of Building Environment Control, University of South China, \\ Hengyang, China \\ ${ }^{3}$ Key Lab of Hunan for the Technologies of Energy Conservation in Prefabricated Buildings, University of South China, \\ Hengyang, China \\ Email: hyy882456789@163.com, *luoqinghai@126.com
}

How to cite this paper: He, Y.Y., Luo, Q.H., Ge, P.H., Chen, G.J. and Wang, H.Q. (2018) Review on Mould Contamination and Hygrothermal Effect in Indoor Environment. Journal of Environmental Protection, 9, 100-110.

https://doi.org/10.4236/jep.2018.92008

Received: January 1, 2018

Accepted: February 20, 2018

Published: February 23, 2018

Copyright (C) 2018 by authors and Scientific Research Publishing Inc. This work is licensed under the Creative Commons Attribution International License (CC BY 4.0)

http://creativecommons.org/licenses/by/4.0/

\begin{abstract}
Mould is an important factor which affects building environment and indoor air quality. Firstly, a variety of damages of mould contamination to human and building are reviewed. Then, the crucial factors of mould growth are analyzed; temperature and humidity are key factors. After that, the indoor mould growth models were analyzed. Heat and moisture transfer in building envelope is a key factor which affects mould growth environment; wall is sensitive to reach the critical condition which leads to mould growth and reproduction, results in contamination.
\end{abstract}

\section{Keywords}

Mould Contamination, Building Environment, Mould Growth Model, Heat and Moisture Transfer

\section{Introduction}

On average, people spend more than $80 \%$ of time everyday indoors, and there are also more than $60 \%$ of the disease associates with indoor pollution. Whatever the level of country development, indoor humidity and mould problems are consistent with respiratory diseases and other symptoms [1] [2], so mould is an important indicator of indoor environment quality. It attaches great importance to the risk of high humidity and mould in the developed countries where the research about indoor mould contamination began earlier, because there is a large proportion of wood structure in many traditional building, some cold space, such as attics and crawl spaces, are also common in the building of developed 
countries. These places are suitable for mould survival [3] [4]. Since the 1990s, more attention has been paying at the air quality of Chinese residential space. The research on the indoor mould problem mainly involves mould contamination monitoring in the environment [5] [6] [7] [8], and the relationship between building mould-moisture problem and human health [8] [9] [10].

This paper summarized the hazard of mould pollution on human health and building environment and the main affecting factors of mould growth and reproduction; the humidity and temperature are the key factors; then discussed a series of prediction models of mould growth. The heat-moisture transfer in the building envelope is an important factor affecting the mould growth environment, which leads to the critical condition of the growth and propagation of mould and the formation of mould pollution. On the basis of this, suggestions are put forward for the risk and control of mould pollution.

\section{The Hazard of Indoor Mould}

\subsection{The Hazard of Mould to Human Health}

Mould contamination poses a health threat associated with people's symptoms of asthma, cough, wheezing, and upper respiratory infections. Mould and its metabolites can be harmful to human body, especially toxic metabolites are more harmful. Mould spores and their tissue fragments may be allergens, which can lead to allergies. The mould can cause harm when they enter the body through the respiratory tract and the esophagus and can be parasitic on the surface of the human body. About 6 to 15 percent of people are allergic to mould, the pathogenic effects are more severe in allergic people [11].

Epidemiological evidence suggests that mould increases the risk respiratory diseases such as allergic rhinitis and asthma [12]. Some of the more toxic moulds may cause serious lung lesions or even death. Mould contamination also can increase the incidence of rare diseases, such as alveolitis, chronic and anaphylactic sinusitis. In addition, indoor mould can also have adverse effects on people's psychology and affect people's work efficiency [13].

\subsection{The Hazard of Mould to Building}

The damage mould work on buildings also can't be ignored. In 1996, The Third Assessment Report published by the German research institute claimed that the annual economic losses caused by mould were more than 200 million Euros [14]. From 1999 to 2000, the number of building insurance complaints in Texas increased 13 times because of mould contamination [15].

Mould can form a lot of ugly stains on the surface of buildings or objects, affects aesthetics. There are many kinds of mould, and the corresponding mycelia comes in different colors, including yellow, green, brown, grey, black and white [16]. Not only does mould contamination may cause corrosion and bulging on stucco coating or paint of wall surface, but also it causing the decaying of wood components, even damaging the structure of the structure, resulting in the ex- 
pansion or extension of concrete structure pores and cracks [17] [18]. It's particularly serious that the influence of mould contamination in the buildings with high requirements for interior decoration.

\section{Influence Factors of Indoor Mould Contamination}

The main factors for mould contamination are spores, favorable growth conditions and exposure time under favorable conditions. Favorable growth conditions mean sufficient nutrients and suitable temperature, humidity, oxygen, $\mathrm{pH}$ value, etc. Moulds are ubiquitous in the building environment, especially in the place with exposed soil structure [14].

Sufficient nutrition is solid foundation for mould growth. Based on the suitability for mould growth, various building materials were classified into four categories by Sedlbauer [14]: Class 0 is the culture medium in laboratory condition which is used as reference; Class I are materials with high nutrient content, such as wallpaper, gypsum board and so on; Class II are mainly porous structure materials like plasters, mineral materials, some woods and insulation materials; Class III are materials that can neither provides nutrition nor be degraded, i.e. mould couldn't growth in these materials, such as metals, glass, tiles, etc. Sedlbauer also find the growth rate Isopleths of Class I and Class II for temperature and relative humidity (Figure 1). However, the dust settled on the surface of the less nutrition material can satisfy the demand of mould growth [19]. Once material is soiled, it can be classified in Class I.

Temperature and humidity are the key and most controllable factors that affect mould growth and reproduction. Spores can survive in extremely adverse environment because of its cell wall which possesses a strong ability for anti-high temperature and anti-radiation [20]. Humidity is the decisive factor in mould growth and reproduction, because spore germination, mycelium growth and release of mycotoxins are strongly dependent on the humidity. On the basis of the water requirements, WHO divided indoor fungi into three levels [21]: 1) primary colonizers, which can grow at a water activity less than or equal to $80 \%$; 2) secondary colonizers, which grow at a water activity level of $80 \%-90 \%$; 3 ) tertiary
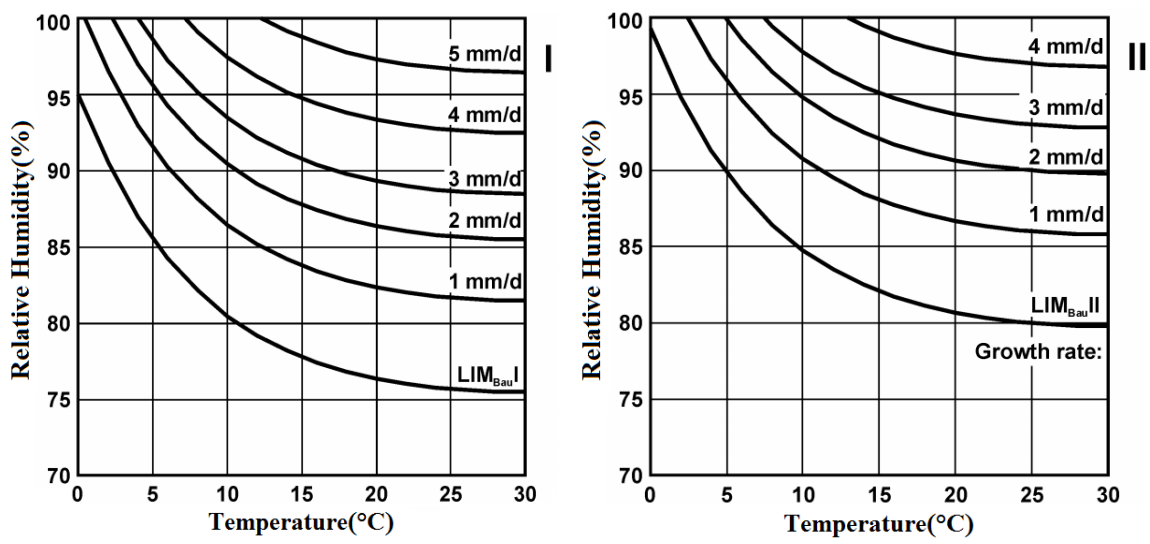

Figure 1. Growth rate isopleths of Class I (left) and Class II (right) by Sedlbauer [14]. 
colonizers, which require a water activity greater than $90 \%$ to germinate and start mycelial growth. Furthermore, WHO use $80 \%$ as relative humidity threshold to prevent mould growth. In general, mould can grows at temperatures between $0^{\circ} \mathrm{C}$ and $50^{\circ} \mathrm{C}$ which range is the great majority indoor temperature within [22]. However, temperature can decide the relative humidity threshold for mould growth. The higher temperature is, the lower relative humidity threshold is [14] [23].

Indoor environment can easily meet the oxygen and $\mathrm{pH}$ value that mould need to growth and reproduction. Mould growth only requires oxygen concentration in the range of $0.14 \%-25 \%$. The optimum $\mathrm{pH}$ range for growth and reproduction of mould is in $5-7$, and many moulds can still grow in the range of $\mathrm{pH} 3$ - 9, some can grow even when the $\mathrm{pH}$ is in 2 - 11 [24].

In summary, all requirements for mould growth are difficult to avoid in building environment except for humidity, and temperature could affect mould growth directly and indirectly, so that control temperature and humidity can prevent mould contamination effectively.

\section{Mould Growth Prediction Model}

Many researches have put forward various indoor mould risk prediction models. Because of the differences in experiment conditions and methods, analysis perspectives and intended use, the prediction results may be greatly different.

\subsection{Steady-State Model}

In the steady-state model, it is considered that the mould begins to grow when the environmental temperature and humidity exceeds the critical condition, i.e. critical growth isopleth given by the model. In the prediction of mould growth, the temperature and humidity are usually using the average value over a certain period of time. The steady-state model is a simple predict method but fails to assess the extent of mould contamination, wherefore it is used for prevention rather than assessment. In addition, steady-state models mainly focus on the effect of temperature and humidity on mould, while ignoring the effects of nutrient.

The following assessment criteria for mould risk has been adapted by ASHARE [25]: With the average surface temperature from $5^{\circ} \mathrm{C}$ to $40^{\circ} \mathrm{C}$, the average surface relative humidity should less than $80 \%$ within 30 days, less than $98 \%$ within 7 days and less than $100 \%$ within 24 hours.

Hens [26] found that Aspergillus versicolor has the lowest critical growth isopleth among various fungi on the inner surface of building. After laboratory studies, the critical relative humidity of Aspergillus versicolor mould was obtained, based on a quadratic function of temperature correspond to the longterm risk, and a logarithmic function of the number of days correspond to the short-term risk. Clarke and Rowan [27] divided indoor common mould into six categories, each category has their own isopleth for temperature and relative 


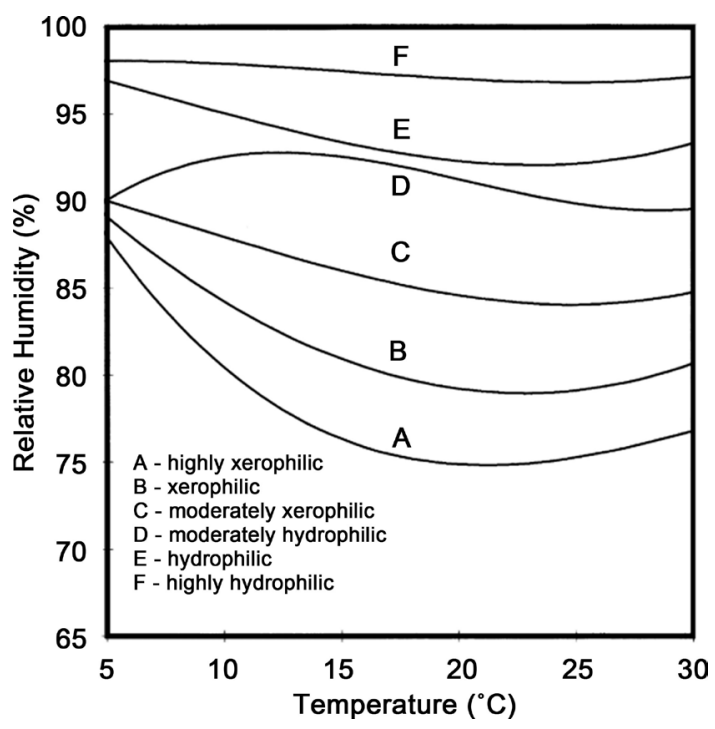

Figure 2. Isopleths of six categories moulds in ESP-r model.

humidity, and specific examples of mould in each category also are included (Figure 2): Highly xerophilic (Aspergillus repens); xerophilic (Aspergillus versicolor); Moderately xerophilic (Penicillium chysogenum); Moderately hydrophilic (Cladosporium sphaerospermum); hydrophilic (Ulocladium consortiale); Highly hydrophilic (Stachybotrys atra). According to a large number of experiments, the temperature and humidity isopleths for six mould categories were got.

\subsection{Transient Model}

In transient model, surrounding temperature and humidity are fluctuating, and mould growth is regarded as the accumulation process. After a period of time spore needs in favorable condition, it will germinate. Transient model can be used as a mould risk assessment for existing buildings; it is credible but more complex and needs to be calculated hourly. Moreover, the transient model used for quantitatively evaluates the extent of mould contamination, and different models have different evaluation indicators.

Adan [28] put mixed fungi under a cycle environment between high-relative humidity and low-relative humidity. The result showed that mould will grow when the ratio of time in a high relative-humidity environment to total time is higher than 0.5. Further, there is a non-linear relationship between the ratio and mould growth extent. Hukka and Viitanen [29] [30] tested common building materials, put forward the VTT model, and used mould index M as mould assessment indicator, which is a piecewise function to express the difference in favorable and unfavorable conditions. Sedlbauer [14] classified common moulds and common materials in the building, and established Biohygrothermal model, used the mycelium growth rate $(\mathrm{mm} /$ year) as the mould risk evaluation indicator. Moon [20] [31] figured that uncertainties can occur at whole building lifecycle and lead to mould growth. He developed a mould performance indicator 
that quantifies all building parameters and environmental parameters what may affect mould growth, and calculated the mould risk for random sampling results over these intervals of parameter values. Finally, the probabilistic mould growth risk assessment was obtained. Comparing with the field-measured results, Moon's assessment results of two buildings in Atlanta and Hawaii are consistent with the actual situation.

\section{Influence and Control of Building Heat and Moisture Transfer on the Mould Growth}

\subsection{Influence of Building Heat and Moisture Transfer on Mould Growth}

Indoor environment and people activities provide favorable condition to mould growth. Heat and moisture transfer in the building envelope is an important factor affect the indoor environment, the process can described below [32]:

$$
\begin{gathered}
\left(\rho_{m} c_{p, m}+\omega c_{p, l}\right) \frac{\partial T}{\partial t}=\nabla\left(\left(\lambda+h_{l v} \delta_{p} \varphi \frac{d p_{s}}{d t}\right) \nabla T+h_{l v} \delta_{p} p_{s} \nabla \varphi\right) \\
\zeta \frac{\partial \varphi}{\partial t}=\nabla\left(\left(\delta_{p} \varphi \frac{d p_{s}}{d T}+K_{l} \rho_{l} R_{D} \ln (\varphi)\right) \nabla T+\left(\delta_{p} p_{s}+K_{l} \rho_{l} R_{D} \frac{T}{\varphi}\right) \nabla \varphi\right) .
\end{gathered}
$$

The heat and moisture transfer are simultaneous and coupled each other. When the relative humidity of wall inside or surface reaches the critical condition, there will be a great mould risk. In actual situation, the transfer process is more complex because of various effect factors, such as water leakage and air infiltration caused by wall crack, types of building materials and wall construction, the time-domain characteristics of climatic geography, and the different building functions and live requirements, all of these may change the position of mould growth and reproduction [33]. In addition, the moisture accumulation inside the wall caused by the poor construction quality is easy to cause greater mould risk in a short time after construction (Figure 3).

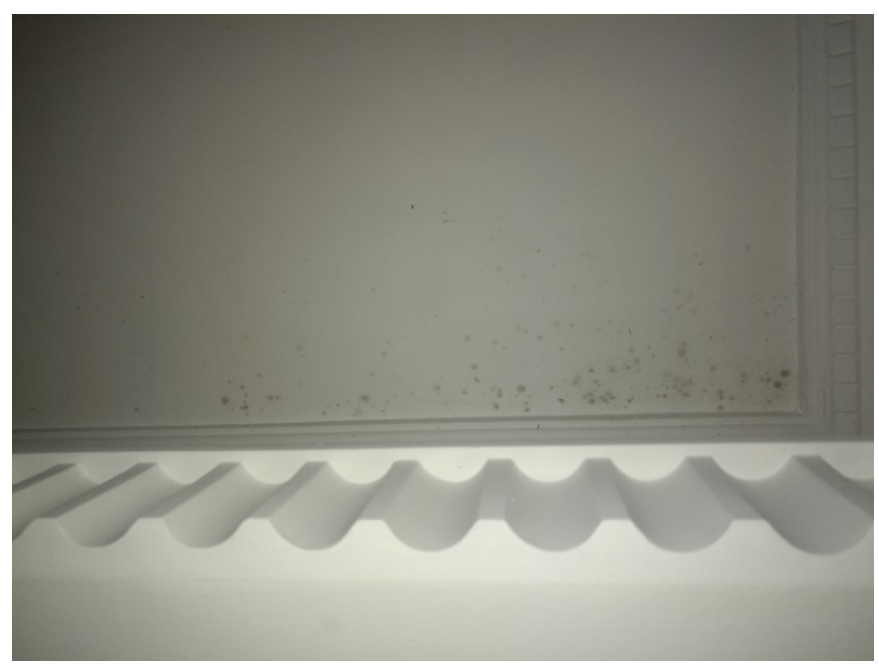

Figure 3. Mould under the ceiling in newly completed building. 
It is easy to form a thermal bridge since the heat transfer performance of doors, windows, columns, beams and other structures is different from the wall materials. It is easier to reach the critical condition and form mould contamination at the interface between the thermal bridge and the surrounding wall [34]. The corner is also easier to reach critical conditions because of its larger contact with the outdoors.

The risk of mould at the bottom and top of the building is incredible high. The ground floors and walls are highly susceptible to moisture transfer from the soil because of the capillary force, resulting in increased moisture content. There is higher risk of mould contamination in the roof because of the possibility of rainwater leakage and the greater exposure to outdoor environment, combined with the impact of habitat activities [35].

The air exchange between indoor and outdoor can also lead to mould contamination. In the high-humidity climate, if the outdoor high-humidity air entered the room through building envelope, it will directly cause the mould multiplication. Even if the outdoor air doesn't meet the critical conditions, it is also easy to reach the critical condition when air contact with colder wall or object, such as the condensation in the moist season in China.

The convective heat transfer coefficient and the convective mass transfer coefficient of the surface are closely related to the surrounding air velocity. Therefore, the air flow state also directly affects the heat and moisture process and results in uneven heat and moisture in all parts. It also explains why mould contamination is easy to appear in the corner and shaded area.

The thermal and moisture storage properties of materials also have influence on mould contamination. For the wildly fluctuate temperature and humidity, good heat and moisture storage property have regulating effect on the peaks of indoor air temperature and humidity [36], and alleviate the mould risk to a certain extent. However, if the relative humidity in the environment is too high, good moisture storage property will allow the material to retain a high moisture content for a longer period of time, which increase the risk of mould contamination.

Resident activities can also contribute to mould contamination. There are a large amount of moisture sources for living activities, such as clean water in bathroom and cooking steam in kitchen, it will rapidly increases the humidity nearby, provides conditions for mould growth and reproduction. More seriously, water vapor may spreads to other indoor spaces and affects the nearby building environment.

In conclusion, the mechanism of heat and moisture transfer in the building environment is very complicated; especially in the areas with high humidity where the critical conditions are easily reach in the indoor environment. Therefore, targeted measures are needed to prevent mould growth.

\subsection{Indoor Mould Contamination Prevention Measures}

Controlling the temperature and relative humidity under critical conditions is 
the key to prevent mould contamination. Therefore, it is necessary to take into account the whole construction environment and analyze the coupling effect of the air.

When calculating the minimum thermal resistance of the building envelope, full consideration should be given to the effect of moisture transfer, determine the minimum thermal resistance of the building envelope for preventing mould growth [37]. It is necessary to make good water-proof and moisture-proof measures for the areas of moisture source, such as the ground floor and toilet. In order to avoid the crack and leakage in the building envelope, thermal insulation and moisture-proof treatment should be done at the thermal bridge.

Emphasize scientific ventilation. When outdoor humidity is relative higher, it is not allowed to enter the room directly; On the contrary, when outdoor humidity is relative lower, ventilation should be strengthened in order to timely discharge the wet air generated by indoor activities, and reduce the moisture content of the building envelope.

To reduce the concentration of spores in the air, it's necessary to reduce the indoor exposed soil components, such as reduce number of plants, and make the paint treatment for mud brick. In addition, regularly ventilation also can reduce the concentration of air spores; Materials that have smooth surface can prevent the accumulation of dust, decrease the number of fungi in the material surface and slow down the proliferation speed; Timely cleaning can make the reduction of the nutrition that mould need and the exposure time of mould in favorable environment.

\section{Conclusions}

Mould is an important factor affects the indoor environment quality of buildings, and mould contamination has serious negative effects on people's health and work efficiency. In this paper, the hazard, influence factors and growth prediction of mould are reported, a serious of thermal and moisture effects in building environment and related measures are discussed.

Mould contamination not only can cause allergic symptom and toxic reaction, but also cause damage to buildings. The factors that influence mould growth and reproduction of mould are easily meet in the living environment; the most important factors are the temperature and humidity, as well as their transmission characteristics. In high-humidity climate areas, the critical conditions for mould growth are more likely reached.

The diversity of building function, building form and material type, as well as the complexity of climate and life style, determine the mould, the uncertainty of the indoor hygrothermal environment and the control of contamination factor. There must be a systematic approach in the mould contamination control, from each step of the whole building lifecycle to the choice of building and furniture material. The difference of building functions and time-domain should be fully considered, and we should take the prevention measures synthetically to build a 
healthy living environment.

\section{References}

[1] Sun, Y., Hou, J., Wang, P., Zhang, Q., Kong, X., Sheng, Y. and Sundell, J. (2015) Dampness Problem in Dwellings at Tianjin and Its Association with Asthma and Allergy among Children. Procedia Engineering, 121, 2163-2167.

https://doi.org/10.1016/j.proeng.2015.09.088

[2] Weinmayr, G., Gehring, U., Genuneit, J., Büchele, G., Kleiner, A., Siebers, R. and Strachan, D.P. (2013) Dampness and Moulds in Relation to Respiratory and Allergic Symptoms in Children: Results from Phase Two of the International Study of Asthma and Allergies in Childhood (ISAAC Phase Two). Clinical \& Experimental Allergy, 43, 762-774. https://doi.org/10.1111/cea.12107

[3] Richter, J. and Staněk, K. (2015) Moisture Safe and Mould Free Crawl Spaces: Stateof-the-Art and Design of Full-Scale Experiment. Energy Procedia, 78, 2754-2759. https://doi.org/10.1016/j.egypro.2015.11.619

[4] Nik, V.M., Sasic Kalagasidis, A. and Kjellström, E. (2012) Assessment of Hygrothermal Performance and Mould Growth Risk in Ventilated Attics in Respect to Possible Climate Changes in Sweden. Building and Environment, 55, 96-109. https://doi.org/10.1016/j.buildenv.2012.01.024

[5] Tian, J. and Wang, C. (2002) Research on Mould on Cultural Relics in the Palace Museum. Northern Cultural Relics, 3, 100-107.

[6] Yuan, Y. and Zhu N. (2003) Research on Mould Contamination Condition in Common Residential Buildings at Dongzhimenwai of Beijing. Disease Surveillance, 18, 433-435.

[7] Wei, X., Han, X., Cui, Y., Zhang, Y. and Huang, C. (2016) Study on Mould Growth in Dwelling Building of Shanghai. Building Energy \& Environment, 35, 26-30.

[8] Wang, X., Liu, W., Huang, C., Cai, J., Shen, L., Zou, Z. and Sundell, J. (2016) Associations of Dwelling Characteristics, Home Dampness, and Lifestyle Behaviors with Indoor Airborne Culturable Fungi: On-Site Inspection in 454 Shanghai Residences. Building and Environment, 102, 159-166. https://doi.org/10.1016/j.buildenv.2016.03.010

[9] Zhang, Y., Li, B., Huang, C., et al. (2013) Ten Cities Cross-Sectional Questionnaire Survey of Children Asthma and Other Allergies in China. Chinese Science Bulletin, 58, 4182-4189. https://doi.org/10.1007/s11434-013-5914-z

[10] Zhao, Z., Zhang, X., Liu, R., et al. (2013) Prenatal and Early Life Home Environment Exposure in Relation to Preschool Children's Asthma, Allergic Rhinitis and Eczema in Taiyuan, China. Chinese Science Bulletin, 58, 4245-4251.

[11] Li, H. (2009) Study on the Relationships between the Indoor Air Pollutants and Childhood Ashtma. Chinese Center for Disease Control and Prevention, Beijing.

[12] Sharpe, R.A., Bearman, N., Thornton, C.R., Husk, K. and Osborne, N.J. (2015) Indoor Fungal Diversity and Asthma: A Meta-Analysis and Systematic Review of Risk Factors. Journal of Allergy and Clinical Immunology, 135, 110-122. https://doi.org/10.1016/j.jaci.2014.07.002

[13] Liddell, C. and Guiney, C. (2015) Living in a Cold and Damp Home: Frameworks for Understanding Impacts on Mental Well-Being. Public Health, 129, 191-199. https://doi.org/10.1016/j.puhe.2014.11.007

[14] Sedlbauer, K. (2001) Prediction of Mould Fungus Formation on the Surface of and inside Building Components. Ph.D. Dissertation, Stuttgart University, Stuttgart. 
[15] Hartwig, R. (2003) Mold and Insurance: Is the Worst behind Us? The Presentation to the Casualty Actuarial Society Seminar on Ratemaking, San Antonio, TX, 27 March 2003.

[16] Zerek, B.F. (2014) Short Mould Review. In: The Preservation and Protection of Library Collections, Chandos Publishing, Oxford, 23-96.

[17] Cwalina, B. (2008) Biodeterioration of Concrete. Architecture Civil Engineering Environment, 1, 133-140.

[18] Sanchez-Silva, M. and Rosowsky, D.V. (2008) Biodeterioration of Construction Materials: State of the Art and Future Challenges. Journal of Materials in Civil Engineering, 20, 352-365. https://doi.org/10.1061/(ASCE)0899-1561(2008)20:5(352)

[19] Adan, O.C. and Samson, R.A. (2011) Fundamentals of Mold Growth in Indoor Environments and Strategies for Healthy Living. Springer Science \& Business Media, Berlin. https://doi.org/10.3920/978-90-8686-722-6

[20] Moon, H.J. (2005) Assessing Mold Risks in Buildings under Uncertainty. Georgia Institute of Technology, Atlanta, GA.

[21] Afshari, A., Anderson, H.R., Cohen, A., Fernandes, E.D.O., Douwes, J., Górny, R. and Kurnitski, J. (2009) WHO Guidelines for Indoor Air Quality: Dampness and Mould. World Health Organization, Geneva.

[22] Baughman, A.V. and Arens, E.A. (1996) Indoor Humidity and Human Health-Part I: Literature Review of Health Effects of Humidity-Influenced Indoor Pollutants. Center for the Built Environment, University of California, Berkeley, CA.

[23] Johansson, P., Ekstrand-Tobin, A. and Bok, G. (2014) An Innovative Test Method for Evaluating the Critical Moisture Level for Mould Growth on Building Materials. Building \& Environment, 81, 404-409. https://doi.org/10.1016/j.buildenv.2014.07.002

[24] Li, N., Li, B. and Hu, J. (2010) Simulation of Mold Growth on Building Walls. Science \& Technology Review, 28, 41-44.

[25] TenWolde, A., Kaskel, B.S., Kudder, R.J., Mitchell, M.R., Link, R.E., TenWolde, A. and Link, R.E. (2008) ASHRAE Standard 160P_Criteria for Moisture Control Design Analysis in Buildings. ASHRAE Transactions, 39, 77-81.

[26] Hens, H. (2003) Mold in Dwellings: Field Studies in a Moderate Climate. Proceedings of the 24th AIVC Conference and BETEC Conference, Ventilation, Humidity Control and Energy, Washington D.C., 12-14 October 2003.

[27] Clarke, J.A., Johnstone, C.M., Kelly, N.J., McLean, R.C., Anderson, J.A., Rowan, N.J. and Smith, J.E. (1999) A Technique for the Prediction of the Conditions Leading to Mould Growth in Buildings. Building and Environment, 34, 515-521. https://doi.org/10.1016/S0360-1323(98)00023-7

[28] Adan, O. (1994) On the Fungal Defacement of Interior Finishes. Technische Universiteit Eindhoven, Eindhoven.

[29] Hukka, A. and Viitanen, H. (1999) A Mathematical Model of Mould Growth on Wooden Material. Wood Science and Technology, 33, 475-485. https://doi.org/10.1007/s002260050131

[30] Lähdesmäki, K., Vinha, J., Viitanen, H., Salminen, K., Peuhkuri, R., Ojanen, T. and Strander, T. (2008) Development of an Improved Model for Mould Growth: Laboratory and Field Experiments. Proceedings of 8 th Nordic Symposium on Building Physics, Copenhagen, 16-18 June 2008.

[31] Moon, H. and Augenbroe, G. (2004) Towards a Practical Mould Growth Risk Indi- 
cator. Building Services Engineering Research and Technology, 25, 317-326. https://doi.org/10.1191/0143624404bt101oa

[32] Liu, X., Chen, Y., Ge, H., Fazio, P. and Chen G. (2015) Numerical Investigation for Thermal Performance of Exterior Walls of Residential Buildings with Moisture Transfer in Hot Summer and Cold Winter Zone of China. Energy \& Buildings, 93, 259-268. https://doi.org/10.1016/j.enbuild.2015.02.016

[33] Liu, X. (2015) Investigation of the Coupled Heat, Air and Moisture Transport in Building Walls in Hot Summer and Cold Winter Zone. Hunan University, Changsha.

[34] Zhu, C. (2008) Study on Causes of Moisture Condensation in Thermal Bridge Position of Building Envelope Structure. Building Energy Efficiency, 36, 6-8.

[35] Wahab, S.N.A., Mohammed, N.I., Khamidi, M.F. and Jamaluddin, N. (2015) Qualitative Assessment of Mould Growth for Higher Education Library Building in Malaysia. Procedia-Social and Behavioral Sciences, 170, 252-261. https://doi.org/10.1016/j.sbspro.2015.01.035

[36] Chen, Y., Chen, Z. and Chen, X. (1999) Simulation of Influence of Moisture Absorption and Desorption in Buildings on Indoor Humidity and Space Cooling Load. Heating Ventilating \& Air Conditioning, 29, 5-9.

[37] Guo, X. and Chen, Y. (2010) Mould Contamination Assessment and Control Strategies of Timber Structure Exposed to Hot-Humid Climate. Journal of Safety and Environment, 10, 113-117. 